\title{
Characterization of the
}

\section{Platelet Prostaglandin $\mathrm{D}_{2}$ Receptor}

\author{
LOSS OF PROSTAGLANDIN $\mathrm{D}_{\mathbf{2}}$ RECEPTORS IN PLATELETS \\ OF PATIENTS WITH MYELOPROLIFERATIVE DISORDERS
}

\author{
BARRY COOPER and DAVID AHERN, West Roxbury Veterans Administration Medical \\ Center; Hematology Division and Department of Medicine, Peter Bent Brigham \\ Hospital; Department of Medicine, Harvard Medical School, Boston, \\ Massachusetts 02115; and New England Nuclear Corporation, \\ Boston, Massachusetts 02118
}

\begin{abstract}
A B S T R A C T Prostaglandin (PG) $\mathrm{D}_{2}$ is synthesized in platelets at concentrations which could inhibit aggregation via activation of adenylate cyclase. To more directly define platelet-PG interactions, a binding assay has been developed for platelet PG receptors with $\left[{ }^{3} \mathrm{H}\right] \mathrm{PGD}_{2}$ as ligand. $\left[{ }^{3} \mathrm{H}\right] \mathrm{PGD}_{2}$ binding to intact platelets was saturable and rapid with the ligand bound by $3 \mathrm{~min}$ at $20^{\circ} \mathrm{C}$. PG competed with the $\left[{ }^{3} \mathrm{H}\right] \mathrm{PGD}_{2}$ binding site with a potency series: $\mathrm{PGD}_{2}\left(\mathrm{IC}_{30}=0.08\right.$ $\mu \mathrm{M}) \gg \mathrm{PGI}_{2} \quad\left(\mathrm{IC}_{50}=2 \mu \mathrm{M}\right)>\mathrm{PGE}_{1} \quad\left(\mathrm{IC}_{50}=6 \mu \mathrm{M}\right)$ $>\mathrm{PGF}_{2 \alpha}\left(\mathrm{IC}_{50}=8 \mu \mathrm{M}\right)$. Scatchard analysis of binding data from six normal subjects showed a single class of binding sites with a dissociation constant $\left(K_{d}\right)$ of $53 \mathrm{nM}$ and 210 binding sites per platelet. This $\mathrm{PGD}_{2}$ receptor assay was then used to study platelets from five patients with myeloproliferative disorders (polycythemia vera, essential thrombocythemia, and chronic myelogenous leukemia), as over $90 \%$ of these patients have platelets resistant to the effects of $\mathrm{PGD}_{2}$ on aggregation and adenylate cyclase activity (1978. Blood. 52: 618-626.). In the presence of $50 \mathrm{nM}\left[{ }^{3} \mathrm{H}\right] \mathrm{PGD}_{2}$, the patients' platelets bound $7.1 \pm 2.9 \mathrm{fmol}$ ligand $/ 10^{8}$ platelets compared with $15.1 \pm 1 \mathrm{fmol} / 10^{8}$ platelets in normals, a decrease of $53 \%(P<0.01)$. Scatchard analysis showed that the $K_{\mathrm{d}}$ of $\left.{ }^{3} \mathrm{H}\right] \mathrm{PGD}_{2}$ binding ( $33 \mathrm{nM}$ ) was comparable to normal platelets, which indicates that the decreased $\mathrm{PGD}_{2}$ binding in these platelets represented fewer receptors rather than altered affinity of the ligand for the binding site. The $53 \%$ decrease in $\left[{ }^{3} \mathrm{H}\right] \mathrm{PGD}_{2}$ binding correlated with a $48 \%$ decrease in $\mathrm{PGD}_{2}$-activated platelet adenylate cyclase. The characterization
\end{abstract}

Received for publication 23 February 1979 and in revised form 23 April 1979. of the platelet $\mathrm{PGD}_{2}$ binding site provides further direct evidence that there are at least two $P G$ receptors on platelets, one for $\mathrm{PGE}_{1}$ and $\mathrm{PGI}_{2}$, and a separate receptor for $\mathrm{PGD}_{2}$. Direct binding analysis will be a useful tool for studying the role of PG in regulating platelet function, as demonstrated by the selective loss of $\mathrm{PGD}_{2}$ binding sites in patients with myeloproliferative disorders.

\section{INTRODUCTION}

There is increasing evidence that prostaglandins and their derivatives may regulate platelet aggregation (1). Whereas certain prostaglandin (PG) ${ }^{1}$ intermediates such as $\mathbf{P G G}_{2}$ and $\mathrm{PGH}_{2}$, as well as thromboxanes, may induce platelet aggregation, other stable PG such as $\mathrm{PGI}_{2}, \mathrm{PGE}_{1}$, and $\mathrm{PGD}_{2}$ are potent inhibitors of platelet aggregation via activation of adenylate cyclase (2-9). $\mathrm{PGI}_{2}$ is synthesized by endothelial cells and may play an important role in mediating platelet-endothelial cell interactions (2). However, of these PG only $\mathrm{PGD}_{2}$ is produced by platelets at sufficient concentrations to potentially inhibit platelet aggregation (9). As such, a binding assay characterizing the platelet $\mathrm{PGD}_{2}$ receptor would be a useful tool to further our understanding of platelet-PG interactions. With the availability of $\left[{ }^{3} \mathrm{H}\right] \mathrm{PGD}_{2}$ for use as a radioligand, such binding studies are now feasible.

Data from other investigators (10-12) and our laboratory (13) have suggested that there is a common platelet receptor for $\mathrm{PGE}_{1}$ and $\mathrm{PGI}_{2}$, which is distinct from

${ }^{1}$ Abbreviations used in this paper: $\mathrm{IC}_{50}$, concentration of unlabeled prostaglandin needed to displace $50 \%$ of $\left[{ }^{3} \mathrm{H}\right] \mathrm{PGD}_{2}$; PG, prostaglandin(s). 
the $\mathrm{PGD}_{2}$ binding site. This hypothesis is also supported by the recent report that platelets from patients with myeloproliferative disorders are resistant to $\mathrm{PGD}_{2}$ but respond normally to $\mathrm{PGI}_{2}$ and $\mathrm{PGE}_{1}$ (14). Platelets from these patients require higher than normal concentrations of $\mathrm{PGD}_{2}$ to inhibit collagen-induced serotonin release, and stimulation of platelet adenylate cyclase by $\mathrm{PGD}_{2}$ is blunted. These studies provide the initial characterization of the platelet $P_{\mathrm{CD}_{2}}$ receptor and demonstrate its use in studying the $\mathrm{PGD}_{2}$ receptor in platelets from patients with myeloproliferative disorders.

\section{METHODS}

Binding assay. Platelet-rich plasma was obtained from 200 $\mathrm{ml}$ of venous blood anticoagulated with $13.5 \%$ acid citrate dextrose (National Institutes of Health Formula A) by centrifugation at $160 \mathrm{~g}$ for $10 \mathrm{~min}$. The platelet-rich plasma was adjusted to $\mathrm{pH} 6.5$ with additional acid citrate dextrose, and a platelet pellet was prepared by centrifugation at $1,500 \mathrm{~g}$ for $10 \mathrm{~min}$. The pellet was suspended in $10 \mathrm{ml}$ of buffer containing $8 \mathrm{mM} \mathrm{Na}_{2} \mathrm{HPO}_{4}, 2 \mathrm{mM} \mathrm{NaH} \mathrm{PO}_{4}, 10 \mathrm{mM}$ EDTA, 5 $\mathrm{mM} \mathrm{KCl}$, and $135 \mathrm{mM} \mathrm{NaCl}, \mathrm{pH} \mathrm{7.2,} \mathrm{and} \mathrm{recentrifuged} \mathrm{at}$ $1,500 \mathrm{~g}$ for $10 \mathrm{~min}$. The supernate was discarded, and the platelet pellet was resuspended in $3.5 \mathrm{ml}$ of assay buffer (138 $\mathrm{mM} \mathrm{NaCl}, 5 \mathrm{mM} \mathrm{MgCl}$, $1 \mathrm{mM}$ EGTA, and $25 \mathrm{mM}$ Tris- $\mathrm{HCl}$, $\mathrm{pH}$ 7.5). If necessary, additional assay buffer was added to obtain a platelet concentration of $1-1.5 \times 10^{8}$ platelets $/ 0.10 \mathrm{ml}$.

Incubations were carried out in a total volume of $200 \mu \mathrm{l}$ which included $100 \mu \mathrm{l}$ of platelet suspension. Unless otherwise stated, the platelets were incubated at $20^{\circ} \mathrm{C}$ for $20 \mathrm{~min}$ with indicated concentrations of $\left[{ }^{3} \mathrm{H}\right] \mathrm{PGD}_{2}$. Separate tubes containing $10 \mu \mathrm{M}$ of nonradioactive $\mathrm{PGD}_{2}$ were included to determine "nonspecific" binding. "Specific binding" was defined as the difference between radioactivity bound in the presence and absence of $10 \mu \mathrm{M} \mathrm{PGD}_{2}$ and is referred to in all figures. Specific binding amounted to $50-60 \%$ of total bound counts. After the incubation, $4 \mathrm{ml}$ of ice-cold buffer (50 $\mathrm{mM}$ Tris/ $\mathrm{HCl}, \mathrm{pH} 7.4$ ) was added to each tube, and the contents were rapidly filtered through a Whatman GF/C glass microfiber filter (Whatman, Inc., Clifton, N. J.) under reduced pressure. Each assay tube and the filter were then washed successively with four 5-ml portions of ice-cold buffer. Whereas nonspecific binding decreased from 50 to $30 \%$ with serial washings, specific binding did not decrease. The filter was then dried, suspended in $10 \mathrm{ml}$ of Beckman Ready-Solv liquid scintillation cocktail (Beckman Instruments, Inc., Fullerton, Calif.), and counted in a Packard Tri-carb scintillation spectrometer (Packard Instrument Co., Downers Grove, Ill.) with an overall efficiency of $60 \%$. $\left[{ }^{3} \mathrm{H}\right] \mathrm{PGD}_{2}(70 \mathrm{Ci} / \mathrm{mmol})$ was provided by New England Nuclear (Boston, Mass.) with a radiochemical purity of $>98 \%$ by high-pressure liquid chromatography. Other PG were a gift from Dr. John Pike (The Upjohn Co., Kalamazoo, Mich.). Platelet counts were performed with an electronic particulate counter (Coulter model ZF, Coulter Electronics, Inc., Hialeah, Fla.).

Calculations. The interaction of $\left[{ }^{3} \mathrm{H}\right] \mathrm{PGD}_{2}$ with platelets was analyzed by the method of Scatchard (15). The dissociation constant $\left(K_{d}\right)$ for $\left[{ }^{3} \mathrm{H}\right] \mathrm{PGD}_{2}$ binding was then determined by linear regression analysis of equilibrium binding data. The concentration of unlabeled PG needed to displace $50 \%$ of the $\left[{ }^{3} \mathrm{H}\right] \mathrm{PGD}_{2}\left(\mathrm{IC}_{50}\right)$ was estimated by visual inspection of the competition curves. The differences between means were assessed by Student's $t$ test.

Adenylate cyclase assay. Platelets from $20 \mathrm{ml}$ of blood were prepared and washed twice in buffer as described above. The platelet pellet was then frozen and thawed in a dry iceacetone bath and suspended in $2 \mathrm{ml}$ of ice-cold Tris-saline (15 mM Tris- $\mathrm{HCl}, 138 \mathrm{mM} \mathrm{NaCl}, \mathrm{pH}$ 7.6). Enzyme activity of the platelet suspension was measured immediately after thawing as previously described (14).

Patients. Five patients with myeloproliferative disorders were selected from the Outpatient Hematology Clinic population of the Peter Bent Brigham Hospital and the West Roxbury Veterans Administration Medical Center. Patients studied included two with polycythemia vera, two with essential thrombocythemia, and one with chronic myelogenous leukemia. Four of these patients were included in a prior report of 23 patients with myeloproliferative disorders having diminished $\mathrm{PGD}_{2}$-sensitive adenylate cyclase activity (14). Patients were not taking any drugs known to interfere with platelet function. The two patients with essential thrombocythemia had elevated platelet counts $\left(>10^{6}\right.$ platelets $\left./ \mathrm{mm}^{3}\right)$, but the other three patients had platelet counts in the normal range. Five patients with reactive thrombocytosis were also studied. These patients averaged $56 \mathrm{yr}$ of age and included one splenectomized patient with beta thalassemia intermedia; three infected, febrile patients; and one patient with Crohn's disease. These patients had platelet counts between 550,000 and $800,000 / \mathrm{mm}^{3}$. The experimental protocol was reviewed and approved by the hospital committee for the protection of human subjects. Platelets from six normal volunteers were also studied, and a normal control was included along with each patient sample for both binding studies and measurement of adenylate cyclase activity.

\section{RESULTS}

Kinetics and specificity of $\left[{ }^{3} \mathrm{H}\right] P G \mathrm{D}_{2}$ binding. Fig. 1 illustrates that $\left[{ }^{3} \mathrm{H}\right] \mathrm{PGD}_{2}$ binding to intact platelets was rapidly saturable and reversible. At $20^{\circ} \mathrm{C}$ most of the ligand was bound within $3 \mathrm{~min}$. Binding was stable for at least $40 \mathrm{~min}$, and the addition of $10 \mu \mathrm{M}$ of unlabeled $\mathrm{PGD}_{2}$ at equilibrium resulted in rapid displacement of $\left[{ }^{3} \mathrm{H}\right] \mathrm{PGD}_{2}$. Because of the rapid binding and dissociation of the ligand, accurate calculation of a rate constant or kinetic $K_{d}$ was not possible. Fig. 2 illustrates the

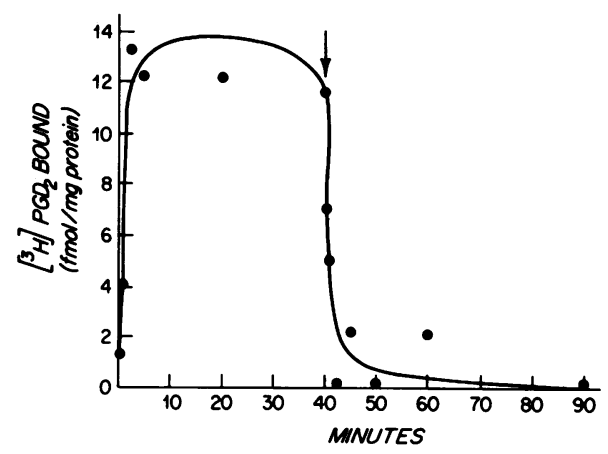

FIgURE 1 Time-course of binding and dissociation of $\left[{ }^{3} \mathrm{H}\right]-$ $\mathrm{PGD}_{2}$ to intact platelets at $20^{\circ} \mathrm{C}$. Platelets were incubated with $3 \mathrm{nM}\left[{ }^{3} \mathrm{H}\right] \mathrm{PGD}_{2}$, and samples were withdrawn at the indicated time. At $40 \mathrm{~min}$ (indicated by arrow) $10 \mu \mathrm{M}$ of unlabeled $\mathrm{PGD}_{2}$ was added to initiate dissociation of $\left[{ }^{3} \mathrm{H}\right] \mathrm{PGD}_{2}$ from the platelets. Each point represents mean of duplicate determinations and is expressed as specific binding. 


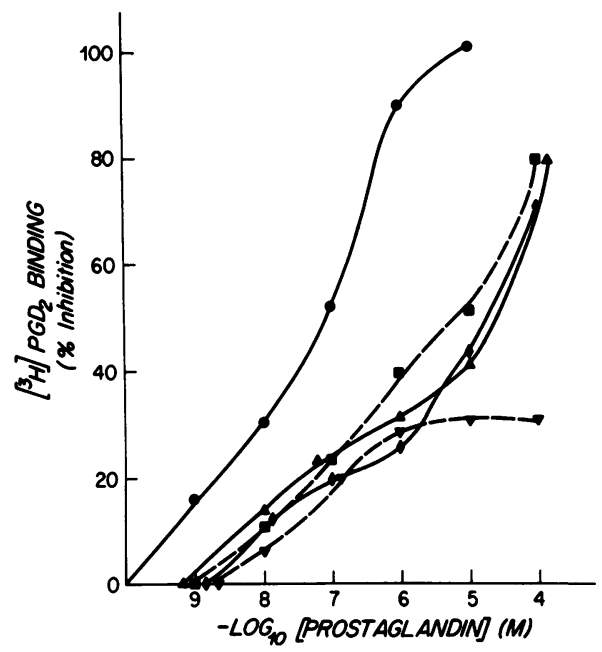

FIGURE 2 Inhibition of $\left[{ }^{3} \mathrm{H}\right] \mathrm{PGD}_{2}$ binding to platelets by $\mathrm{PGD}_{2}(\bullet), \mathrm{PGI}_{2}(\square), \mathrm{PGE}_{1}(\diamond), \mathrm{PGF}_{2 \alpha}(\Delta)$, and $\mathrm{PGE}_{2}(\nabla)$. $\left[{ }^{3} \mathrm{H}\right] \mathrm{PGD}_{2}$ at a concentration of $4 \mathrm{nM}$ was incubated for 20 min at $20^{\circ} \mathrm{C}$ with PG at the concentrations indicated. Results are expressed as percent inhibition of $\left[{ }^{3} \mathrm{H}\right] \mathrm{PGD}_{2}$ binding in the absence of added unlabeled PG. Each point represents the mean of two experiments with duplicate determinations at each point.

ability of unlabeled PG to compete for the $\left[{ }^{3} \mathrm{H}\right] \mathrm{PGD}_{2}$ binding site. There was a reproducible potency series in inhibiting $\left[{ }^{3} \mathrm{H}\right] \mathrm{PGD}_{2}$ binding. $\mathrm{PGI}_{2}\left(\mathrm{IC}_{50}=2 \mu \mathrm{M}\right)$ competed closely with $\mathrm{PGE}_{1}\left(\mathrm{IC}_{50}=6 \mu \mathrm{M}\right)$ and $\mathrm{PGF}_{2 \alpha}$ $\left(\mathrm{IC}_{50}=8 \mu \mathrm{M}\right)$, but all required 100 -fold greater concentrations than $\mathrm{PGD}_{2}\left(\mathrm{IC}_{50}=0.08 \mu \mathrm{M}\right)$. $\mathrm{PGE}_{2}$ competed very poorly with only $30 \%$ displacement of the label at $0.1 \mathrm{mM}$.

Saturability and affinity of $\left[{ }^{3} \mathrm{H}\right] P G D_{2}$ binding. The pattern of $\left[{ }^{3} \mathrm{H}\right] \mathrm{PGD}_{2}$ binding to intact platelets is shown in Fig. 3. Saturation occurred at $30 \mathrm{fmol}$ ligand bound/ $10^{8}$ platelets. At a ligand concentration of $50 \mathrm{nM}$, onehalf of the binding sites were occupied. This value gives an estimate of the $K_{\mathrm{d}}$ of $\left[{ }^{3} \mathrm{H}\right] \mathrm{PGD}_{2}$ for the binding sites. Analysis of the data by Scatchard plot (Fig. 3, inset) demonstrated a single class of binding sites with a $K_{\mathrm{d}}$ of $54 \mathrm{nM}$. This analysis gave an estimate of 35 fmol ligand bound $/ 10^{8}$ platelets, which represents 210 binding sites per platelet.

$\left.{ }^{3} \mathrm{H}\right] P G D_{2}$ binding in myeloproliferative disorders. To determine $\left[{ }^{3} \mathrm{H}\right] \mathrm{PGD}_{2}$ binding to platelets from patients with myeloproliferative disorders, ligand binding was studied with $54 \mathrm{nM} \mathrm{PGD}_{2}$. This concentration of PG approximates the $K_{\mathrm{d}}$ of $\left[{ }^{3} \mathrm{H}\right] \mathrm{PGD}_{2}$ for the binding sites. In normal platelets, $15.1 \pm 1 \mathrm{fmol}$ ligand bound $/ 10^{8}$ platelets was noted, whereas in the patients there was only $7.1 \pm 2.9 \mathrm{fmol}$ ligand bound $/ 10^{8}$ platelets, a decrease of $53 \%(P<0.01)$. Although altered platelet size in these patients could theoretically account for part of

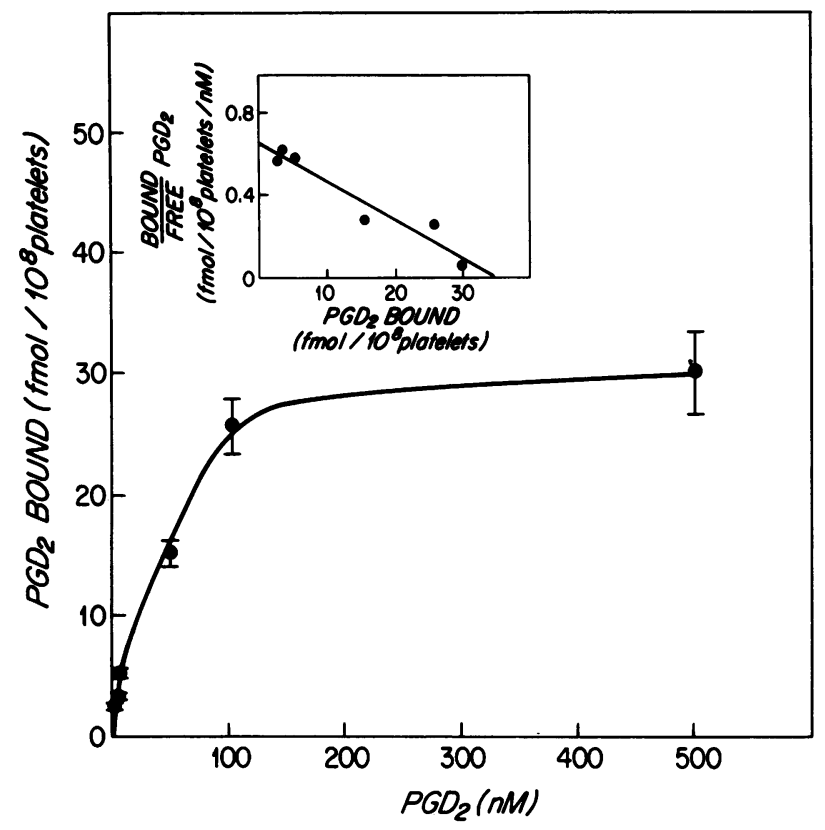

FIGURE 3 The binding of $\left[{ }^{3} \mathrm{H}\right] \mathrm{PGD}_{2}$ to intact platelets is depicted. Mean values $\pm S E M$ of triplicate determinations from six separate experiments are shown. Platelets were incubated with $4 \mathrm{nM}\left[{ }^{3} \mathrm{H}\right] \mathrm{PGD}_{2}$ plus 0 to $10 \mu \mathrm{M}$ of unlabeled $\mathrm{PGD}_{2}$ for $20 \mathrm{~min}$ at $20^{\circ} \mathrm{C}$. Total binding was determined for each point by dividing counts per minute by the calculated specific activity obtained by diluting $4 \mathrm{nM}\left[{ }^{3} \mathrm{H}\right] \mathrm{PGD}_{2}$ with a known concentration of unlabeled $\mathrm{PGD}_{2}$. The inset shows the Scatchard analysis of this data. The line represents the least squares fit of the data points and has a slope of $-0.18 \times 10^{9} \mathrm{M}(r$ $=0.96$ ). The reciprocal of the slope, the $K_{d}$, equals $54 \mathrm{nM}$. The intercept of the line with the ordinate gives an estimate of $35 \mathrm{fmol}$ receptor $/ 10^{8}$ platelets.

this discrepancy, this variable is unlikely because three of the five patients had normal platelet counts and the average protein per platelet in patients $\left(3.5 \pm 0.4 \mathrm{mg} / 10^{9}\right.$ platelets) was the same as normals $\left(3.5 \pm 0.3 \mathrm{mg} / 1^{9}\right.$ platelets). In addition, five patients with reactive thrombocytosis were studied, and platelets from all these individuals had normal $\mathrm{PGD}_{2}$ binding with 17.8 $\pm 3.0 \mathrm{fmol}$ ligand bound $/ 10^{8}$ platelets in the presence of $54 \mathrm{nM} \mathrm{PGD}_{2}$.

To determine whether the diminished $\mathrm{PGD}_{2}$ binding noted in platelets from patients with myeloproliferative disorders represented decreased numbers of binding sites, rather than an altered affinity of the ligand for receptor, a saturation curve was carried out in one patient. As shown in Fig. 4, Scatchard analysis indicated that, like normal platelets, the patient's platelets contained a single class of binding sites. The $K_{d}$ of $33 \mathrm{nM}$ is comparable to the $K_{\mathrm{d}}$ of $54 \mathrm{nM}$ of normal platelets, but only $11 \mathrm{fmol}$ ligand $/ 10^{8}$ platelets were bound (66 receptors per platelet) compared with the $35 \mathrm{fmol}$ bound $/ 10^{8}$ platelets in normals (Fig. 3 ). These 


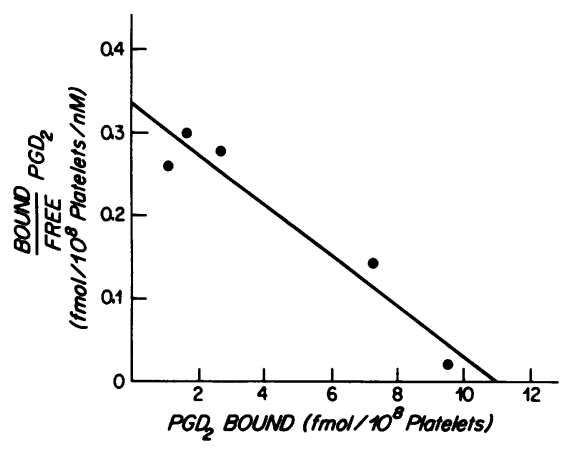

FIGURE 4 Scatchard analysis of $\left[{ }^{3} \mathrm{H}\right] \mathrm{PGD}_{2}$ binding to platelets in a patient with myeloproliferative disorder. Platelets were incubated under conditions described in Fig. 2. Each point represents the mean of triplicate determinations. The line represents the least squares fit of the data points $(r=0.97)$ with a slope of $-0.030 \times 10^{9} \mathrm{M}$. The $K_{d}=33 \mathrm{nM}$ with an estimated $11 \mathrm{fmol}$ receptor $/ 10^{8}$ platelets.

data indicate that the abnormal platelets contain fewer $\mathrm{PGD}_{2}$ binding sites rather than altered affinity of the ligand for the receptor.

Adenylate cyclase activity. Fig. 5 compares the $\mathrm{PGD}_{2}$-sensitive platelet adenylate cyclase activity in the five patients with normal platelets. Dose-response curves show decreased stimulation of the patient's adenylate cyclase at all concentrations of $\mathrm{PGD}_{2}$. In the presence of $0.1 \mu \mathrm{M} \mathrm{PGD}_{2}$ there was 5.8-fold enzyme activation in normal platelets compared with 2.3 -fold enhancement in those of patients. At the highest concentration of $\mathrm{PGD}_{2}$ tested $(10 \mu \mathrm{M})$ the $\mathrm{PGD}_{2}$ activated adenylate cyclase 16.5 -fold in controls as compared with only 8.6-fold in the patients, a decrease of $48 \%$. In contrast with the decreased stimulation observed with $\mathrm{PGD}_{2}$, maximal enzyme stimulation by $\mathrm{PGE}_{1}(29$ \pm 2 times basal) was the same as normals ( $28 \pm 2$ times basal). In addition, enzyme activation by sodium fluoride $(6.7 \pm 0.4$ times basal) in the patients was in the normal range (7.0 \pm 0.6$)$, and basal activity was comparable for the patients and normals (both: $0.1 \mathrm{nM}$ cyclic AMP/mg protein per $10 \mathrm{~min}$ ). Finally, the concentration of $\mathrm{PGD}_{2}$ required for half-maximal stimulation of adenylate cyclase in the patients $(0.7 \mu \mathrm{M})$ was comparable to normal platelets $(0.3 \mu \mathrm{M})$.

\section{DISCUSSION}

These studies demonstrate that the binding of $\left[{ }^{3} \mathrm{H}\right]-$ $\mathrm{PGD}_{2}$ to intact platelets is rapid, reversible, and saturable. There is excellent correlation between the binding $K_{\mathrm{d}}(54 \mathrm{nM})$, the previously reported (14) half-maximal concentration of $\mathrm{PGD}_{2}$ needed to inhibit collagen-induced serotonin release ( $50 \mathrm{nM})$, and the concentration of $\mathrm{PGD}_{2}$ required for half-maximal stimulation of adenylate cyclase $(300 \mathrm{nM})$. The slightly (sixfold)

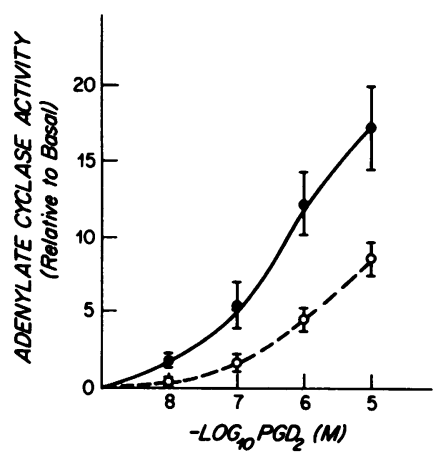

Figure 5 Effects of $\mathrm{PGD}_{2}$ on platelet adenylate cyclase activity in normals $(O)$ and in patients with myeloproliferative disease (O). Enzyme activity is expressed as a ratio of stimulated to basal activity. Mean \pm SEM for five normals and five patients.

higher concentration of $\mathrm{PGD}_{2}$ required to produce halfmaximal stimulation of adenylate cyclase than to cause half-maximal displacement of $\left[{ }^{3} \mathrm{H}\right] \mathrm{PGD}_{2}$ binding has also been noted in $\beta$-adrenergic receptor systems (16) and PG receptor systems (17), and is probably because the nucleotide (ATP) present in the enzyme assay, but not in the binding assay, decreases the affinity of the PG for the receptor.

With the characterization of the platelet $\mathrm{PGD}_{2}$ receptor, there is direct evidence for at least two platelet $P G$ receptors. $P E_{1}$ and $P I_{2}$ compete very poorly with $\left[{ }^{3} \mathrm{H}\right] \mathrm{PGD}_{2}$, whereas the previously reported competition of these two PG for $\left[{ }^{3} \mathrm{H}\right] \mathrm{PGE}_{1}$ and $\left[{ }^{3} \mathrm{H}\right] \mathrm{PGI}_{2}$ correlated with their potent effects on platelet adenylate cyclase and on platelet aggregation $(12,13)$. In these prior studies $\mathrm{PGD}_{2}$ competed very poorly for $\left[{ }^{3} \mathrm{H}\right] \mathrm{PGE}_{1}$ $\left(\mathrm{IC}_{50}=70 \mu \mathrm{M}\right)$, or $\left[{ }^{3} \mathrm{H}\right] \mathrm{PGI}_{2}\left(\mathrm{IC}_{50}>100 \mu \mathrm{M}\right)$, values over 1,000-fold greater than noted in our assay ( $54 \mathrm{nM})$.

The fact that platelets of patients with myeloproliferative disorders have a selective resistance to $\mathrm{PGD}_{2}$ further supports the presence of at least two platelet PG receptors. We recently studied patients with polycythemia vera, chronic myelogenous leukemia, essential thrombocythemia, and myeloid metaplasia (14) and found that these patients required 10-fold higher than normal concentrations of $\mathrm{PGD}_{2}$ to inhibit collageninduced platelet serotonin release. Whereas stimulation of platelet adenylate cyclase by $\mathrm{PGE}_{1}, \mathrm{PGI}_{2}$, and sodium fluoride was normal, enzyme stimulation by $\mathrm{PGD}_{2}$ was blunted in $90 \%$ of the 23 patients studied and correlated with the serotonin-release data found with intact platelets. We postulated that decreased platelet $\mathrm{PGD}_{2}$ receptors, or altered affinity of the ligand for the binding site, probably accounted for these observations. With the radioligand binding assay for $\mathrm{PGD}_{2}$, we now find that these patients have lost $53 \%$ of their $\mathrm{PGD}_{2}$ binding sites but have retained normal 
receptor-ligand affinity. Moreover, this loss of $\mathrm{PGD}_{2}$ receptors correlates with the $50 \%$ decrease in maximal platelet adenylate cyclase activation.

The role of $\mathrm{PGD}_{2}$ in platelet metabolism has not been clarified. Because sufficient quantities of this PG $(17 \mathrm{nM})$ are released into plasma during aggregation to potentially inhibit platelet aggregation (9), it is theoretically possible, although not yet demonstrated, that this PG could play a physiologic role in the regulation of platelet aggregation (6-9). Characterization of the $\mathrm{PGD}_{2}$ platelet receptor, as well as the identification of certain platelets that have decreased number of these receptors, may lead to a better understanding of platelet-PG interactions.

\section{ACKNOWLEDGMENTS}

The excellent technical assistance of Peter Schwarz and the advice and encouragement of Robert I. Handin, Andrew I. Schafer, and R. Wayne Alexander were invaluable. The secretarial help of Clare Smith was greatly appreciated.

\section{REFERENCES}

1. Marcus, A. J. 1978. The role of lipids in platelet function. J. Lipid Res. 19: 793-826.

2. Moncada, S., E. A. Higgs, and J. R. Vane. 1977. Human arterial and venous tissues generate prostacyclin (prostaglandin X) a potent inhibitor of platelet aggregation. Lancet. I: 216-218.

3. Tateson, J. E., S. Moncada, and J. R. Vane. 1977. Effects of prostacyclin (PGX) on cyclic AMP concentration in human platelets. Prostaglandins. 13: 389-397.

4. Gorman, R. R., S. Bunting, and O. V. Miller. 1977. Modulation of human platelet adenylate cyclase by prostacyclin (PGX). Prostaglandins. 13: 377-387.

5. Kloeze, J. 1967. Influence of prostaglandins on platelet adhesiveness and platelet aggregation. In Nobel Symposium 2. Prostaglandins. S. Bergstrom and B. Sam- uelsson, editors. Interscience Pubs., Inc., John Wiley \& Sons, Inc., New York. 241-252.

6. Smith, J. B., M. J. Silver, C. M. Ingerman, and J. J. Kocsis. 1974. Prostaglandin $D_{2}$ inhibits the aggregation of human platelets. Thromb. Res. 5: 291-299.

7. Mills, D. C., and D. E. MacFarlane. 1974. Stimulation of human platelet adenylate cyclase by prostaglandin $\mathrm{D}_{2}$. Thromb. Res. 5: 401-412.

8. Nishizawa, E. E., W. L. Miller, R. Gorman, G. L. Bundy, J. Svenson, and M. Hamberg. 1975. Prostaglandin $\mathrm{D}_{2}$ as a potential antithrombotic agent. Prostaglandins. 9: 109121.

9. Oelz, O., R. Oelz, H. R. Knapp, B. J. Sweetman, and J. A. Oates. 1977. Biosynthesis of prostaglandin $\mathrm{D}_{2}$ : formation by human platelets. Prostaglandins. 13: 225-234.

10. Mills, D. C. B., and D. E. MacFarlane. 1977. Prostaglandins and platelet adenylate cyclase. In Prostaglandins in Hematology. M. J. Silver, J. B. Smith, and J. J. Kocsis, editors. Spectrum Publications, Inc., New York. 219-233.

11. Mills, D. C. B., D. E. MacFarlane, and K. C. Nicolaou. 1977. Interaction of prostacyclin $\left(\mathrm{PGI}_{2}\right)$ with the prostaglandin receptor on human platelets that regulate adenylate cyclase activity. Blood. 50(Suppl): 247A. (Abstr.)

12. Siegl, A. M., J. B. Smith, M. J. Silver, K. C. Nicolaou, and D. Ahern. 1979. Selective binding site for $\left[{ }^{3} \mathrm{H}\right]$ prostacyclin on platelets. J. Clin. Invest. 63: 215-220.

13. Schafer, A. I., B. Cooper, D. O'Hara, and R. I. Handin. 1979. Identification of platelet receptors for prostaglandin $\mathrm{I}_{2}$ and $\mathrm{D}_{2}$. J. Biol. Chem. 254: 2914-2917.

14. Cooper, B., A. I. Schafer, D. Puchalsky, and R. I. Handin. 1978. Platelet resistance to prostaglandin $D_{2}$ in patients with myeloproliferative disorders. Blood. 52: 618-626.

15. Scatchard, G. 1949. The attraction of proteins for small molecules and ions. Ann. N. Y. Acad. Sci. 51: 660-672.

16. Lefkowitz, R. J., D. Mulliken, and M. G. Caron. 1976. Regulation of $\beta$-adrenergic receptors by guanyl-5-yl imidodiphosphate and other purine nucleotides. J. Biol. Chem. 251: 4686-4692.

17. Lefkowitz, R. J., D. Mulliken, C. L. Wood, T. B. Gore, and C. Mukherjee. 1977. Regulation of prostaglandin receptors by prostaglandins and guanine nucleotides in frog erythrocytes. J. Biol. Chem. 252: 5295-5303. 